\title{
HMGA1 wt Allele
}

National Cancer Institute

\section{Source}

National Cancer Institute. HMGA1 wt Allele. NCI Thesaurus. Code C52074.

Human HMGA1 wild-type allele is located within $6 \mathrm{p} 21$ and is approximately $9 \mathrm{~kb}$ in length. This allele, which encodes high mobility group protein HMG-I/HMG-Y, is involved in chromatin remodeling, DNA-dependent transcriptional regulation and inhibition of tumor suppressor p53 protein-dependent apoptosis. The HMGA1 gene is overexpressed in certain types of cancer including breast carcinoma, colorectal cancer, non-small-cell lung carcinoma, epithelial ovarian carcinoma and thyroid cancer. 